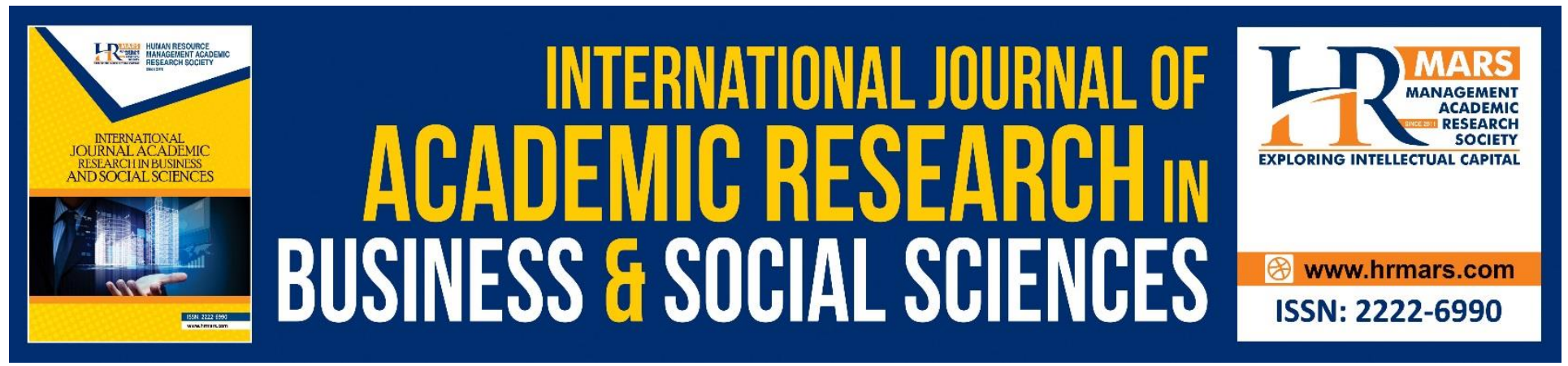

\title{
Measurement Model of Sociality, Innovation and Market Orientation Using Confirmatory Factor Analysis in Social Entrepreneurship Context
}

Hariyaty Ab Wahid, Wan Salmuni Wan Mustaffa, Rafiduraida Abdul Rahman, Norlaile Salleh Hudin

To Link this Article: http://dx.doi.org/10.6007/IJARBSS/v8-i11/4886

DOI: $10.6007 /$ IJARBSS/v8-i11/4886

Received: 26 Sept 2018, Revised: 13 Oct 2018, Accepted: 06 Nov 2018

Published Online: 23 Nov 2018

In-Text Citation: (Wahid, Mustaffa, Rahman, \& Hudin, 2018)

To Cite this Article: Wahid, H. A., Mustaffa, W. S. W., Rahman, R. A., \& Hudin, N. S. (2018). Measurement Model of Sociality, Innovation and Market Orientation Using Confirmatory Factor Analysis in Social

Entrepreneurship Context. International Journal of Academic Research in Business and Social Sciences, 8(11), 76-96.

Copyright: (c) 2018 The Author(s)

Published by Human Resource Management Academic Research Society (www.hrmars.com)

This article is published under the Creative Commons Attribution (CC BY 4.0) license. Anyone may reproduce, distribute, translate and create derivative works of this article (for both commercial and non-commercial purposes), subject to full attribution to the original publication and authors. The full terms of this license may be seen

at: http://creativecommons.org/licences/by/4.0/legalcode

Vol. 8, No. 11, 2018, Pg. 76 - 96

http://hrmars.com/index.php/pages/detail/IJARBSS

JOURNAL HOMEPAGE

Full Terms \& Conditions of access and use can be found at http://hrmars.com/index.php/pages/detail/publication-ethics 


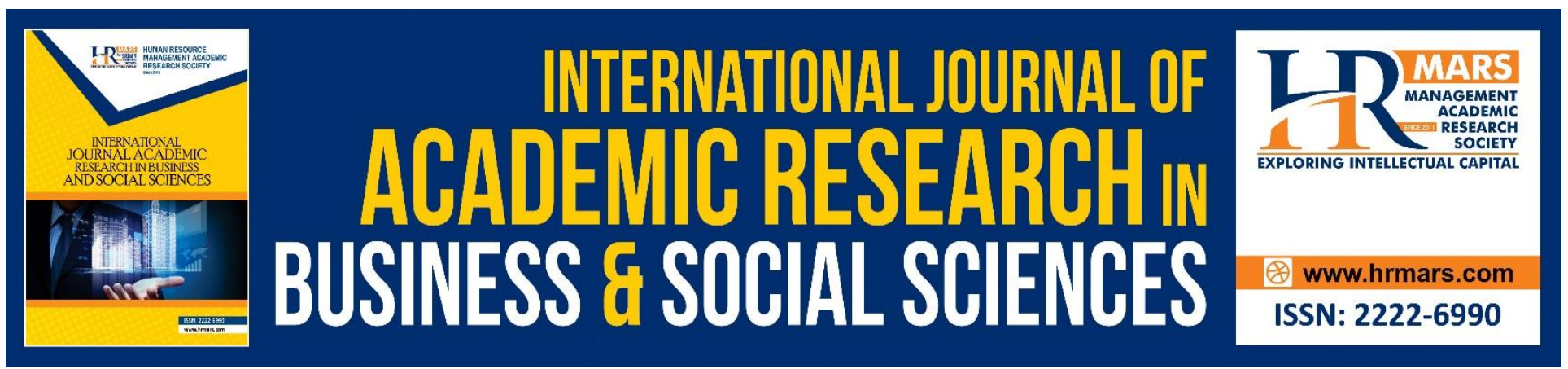

\title{
Measurement Model of Sociality, Innovation and Market Orientation Using Confirmatory Factor Analysis in Social Entrepreneurship Context
}

\author{
Hariyaty Ab Wahid, Wan Salmuni Wan Mustaffa, Rafiduraida Abdul \\ Rahman, Norlaile Salleh Hudin \\ Universiti Pendidikan Sultan Idris, Malaysia
}

\begin{abstract}
University students are the potential human capital that must be inculcated with appropriate skills and good values to develop the exemplary and towering personal qualities in them. In this regard, they are encouraged to be exposed to social entrepreneurship programs that allow them to apply entrepreneurial skills in solving community problems. Such program is expected to foster the social entrepreneurial characters such as sociable, innovative and market oriented. In order to carried out an effective social entrepreneurship program, an accurate measuring tool which is beneficial for measuring the dimensions of social entrepreneurship must be developed. Thus, this paper reports on a study carried out to validate the social entrepreneurship (SE) measurement model for each of the constructs (sociality, innovation and market orientation) using AMOS software. The findings show that the Cronbach Alpha on the classification is higher than 0.7. The results of the first and second order CFA confirmed that data collected fit the model. It is hoped that the proposed measurement model is suitable to be used to measure the social entrepreneurship dimension among university students in Malaysia.
\end{abstract}

Keywords: Social Entrepreneurship, Confirmatory Factor Analysis (CFA), Measurement Model

\section{Introduction}

In Malaysia, the government through its high education system emphasizes entrepreneurial education as one of the platforms to hone and develop entrepreneurial personality among university students at tertiary level. Entrepreneurship education has been identified as one of the strategies to increase the number of skilled manpower, able to develop innovation and technology as well as to encourage the involvement of the community in the business field by 2020 . Consequently, the graduates' unemployment rate is expected to be reduced if the number of graduates entrepreneurs can be increased. 
In higher education, public universities are required to offer programs and courses related to entrepreneurship education since 2007. This situation is further reinforced by the existence of the HEls Entrepreneurship Development Policy in 2010 which opens wide space for students to embark on and apply existing knowledge and experience in the entrepreneurial real world (Ministry of Higher Education, 2007; HEl's Entrepreneur Development Policy 2010). For that purpose, the government has allocated money to conduct entrepreneurship courses in the hope of producing quality and competitive graduates as well as making balanced people with many good values as this is one of the mechanisms practical to address the unemployment problem among graduates (Hashim \& Radio, 2011). This is a concerted effort related to secondary education that has earlier exposed the secondary school students with entrepreneurial education through Life Skills subjects for Form One to Form Three students; and Commerce subjects for Form Four to Five students (Farhana, 2013; Norhamizah 2017). This is to create awareness among the students and attract them to venture into small businesses in the future.

Through the entrepreneurship platform, the Institute of Higher Education (IHE) is encouraged to apply social entrepreneurship to students to produce altruistic and holistic graduates. University students need to be tackled with social entrepreneurship due to the minimum comprehension of the fundamental human skills, the inability to master social skills well and not to highlight the effective morals in society. In addition, there are also a number of university students reported being selfish and not fond of helping colleagues, especially to engage in community-based activities outside the campus. Social entrepreneurship is an educational platform that is expected to provide opportunities for university students to sharpen their social skills, develop self-esteem, empower entrepreneurship and be more altruistic (Hariyaty et al., 2018). Consequently, this research paper aims to fathom the concepts and theories relating to social entrepreneurship dimension and relevant recommendations to be guided towards nurturing social entrepreneurship programs at universities.

Although there is an increase interest in researching on social entrepreneurship, the empirical studies focusing on the exact dimension of social entrepreneurship and its measurement are still at scant (Perrini \& Vurro 2010; Sommerrock 2010; Katono 2011, Hariyaty et al. 2016). The social issues and data associated with recent social entrepreneurship phenomena are limited to case studies, as well as analytical instruments on the efficiency and practice of social enterprise operations. Thus, studies on social entrepreneurship are still growing with the obscure validity until execution of empirical studies that will validate the existing theories being done (Busenitz et al., 2003; Perrini \& Vurro 2010).

Hence, this study is motivated by the above recommendations and as an attempt to ensure that the level of human capital development can be enhanced through a social entrepreneurial approach. This empirical study is one of the continuous effort to identifying the most accurate social entrepreneurial measurement models that can be used to gauge the levels of sociality, innovation and market orientation aiming the students who involve in social entrepreneurship endeavor. The measurement model obtained from this study must show its compatibility with the research data and portray the sound convergence and divergence of validity. The findings of this study is not only made useful to support the existing social entrepreneurship theory and to add value to the dimensions of social 
INTERNATIONAL JOURNAL OF ACADEMIC RESEARCH IN BUSINESS AND SOCIAL SCIENCES

Vol. 8, No. 11, Nov, 2018, E-ISSN: 2222-6990 (C) 2018 HRMARS

entrepreneurship; but also to constitute precise indicators that can be used to measure the three stipulated dimensions of social entrepreneurship in the context of Malaysian university students.

\section{Literature Review}

Social entrepreneurship is a field that often borrow the sociological theory as the backbone of its related studies. Studies on social entrepreneurship commonly located in the business studies group that examine the tendency for entrepreneurs to apply innovative practices (Hariyaty et al. 2018; Emerson 2003). Social entrepreneurship has also become one of the practice and field of research of scholars who provide a unique opportunity to be challenged (Norasmah \& Hariyaty 2014; Mair \& Marti 2005).

In the western context, social entrepreneurship is regarded as a non-profit based venture but creates social values or changes by addressing social challenges using innovation, innovative processes, or managing fund strategies by those with high entrepreneurship and ethics (Mair \& Marti 2005). While in Asian context whose covering most developing countries, the definition of social entrepreneurship is similar to the above terms except that it also requires financial gain (Prahalad 2005) and requires not only the leadership of social entrepreneurship but also the grassroots entrepreneurs (Bornstein 2007). Specifically, social entrepreneurship includes activities or processes that employ entrepreneurial skills, involving innovation and risk taking in implementing social change in a period of time, involving all or part of society in the process of implementing it and the outcome of the processes will benefits the community in total (Norasmah \& Hariyaty 2014; Tan et al. 2002).

Having taken into account the views of the traditional entrepreneurship literature and the anecdotal evidence in social entrepreneurship, the behavior and determination to create social venture efforts is influenced by the desire and feasibility of the social venture efforts (Mazura 2015; Mair and Noboa 2003). The desire for venture is comprised of attitudes that include empathy and moral considerations. Whereas, the feasibility of social exploration efforts is likely to include social support elements and confidence in self efficacy (Norasmah et al. 2014). Empathy is also described as a characteristic of a stable personality and can be developed from time to times. Thus, the study of social entrepreneurship often begun with the personality aspect for the researchers to explore several phenomenon related to individuals or organizations (Norasmah \& Hariyaty 2014).

Previous social entrepreneurship scholars have proposed that the quality that the altruistic trait that exists in the individual social entrepreneurs should be inculcated and cultured among the university students (Hariyaty et al. 2016; Norlela et al. 2016; Suraini et al. 2016). University students who engage in social entrepreneurial activity are expected to become altruistic which can be identified possessing the following criterion:

i. empathy - ability to feel, understand and care about the feelings experienced by others.

ii. voluntary - there is no desire to get a counter-claim.

iii. The desire to help - a strong desire to provide assistance to others without being recognized by anyone. 
This is because social entrepreneurs are seen as the individuals who always possess innovative solutions to deal with the pressing social problems facing by the community (Radin Siti Aishah et al., 2016). They are also individuals who help towards economic progress by finding a new way or a better way of doing things. What is interesting about social entrepreneurs is that they are social entrepreneurial leaders of ordinary people who make extraordinary things (Brooks 2009; Verma, 2009).

Therefore, university students should be encouraged and encouraged to build their social entrepreneurial determination. In the western context, social entrepreneurship is regarded as a nonprofit based venture but creates social values or changes by addressing social challenges using innovation, innovative processes, or managing fund strategies by those with high entrepreneurship and ethics (Norasmah \& Hariyaty 2014; Mair \& Marti 2005). While in Asia which covers most of the developing countries, the definition of social entrepreneurship is similar to the above terms except that it also requires financial gain and requires not only social entrepreneurial leadership but also the birth of grassroots entrepreneurs (Bornstein 2007).

According to Nicholls and Cho (2008), social entrepreneurship is a series of organizational activities that cover three important categories of socialism, innovation and market orientation. Socialism is a dimension in which an organization works with the intention of achieving effective social objectives effectively (Nicholls \& Cho 2008). Nichols and Cho's statements coincide with Marshall's study (2010), and Nga and Shamuganathan (2010) agree that the organization of social entrepreneurship contains a real social element that embodies an explicit social mission that will affect how social entrepreneurs perceive and assess opportunities. Social entrepreneurship is an entrepreneurial approach that is still at the baby stage and evolves with entrepreneurial education itself (Borstein \& Davis 2010; Gatchalian 2010; Megre et al., 2012; Suraya \& Ahmad Rafflis 2015).

However, the entrepreneurial approach and value introduced through this social entrepreneurship is very significant to the dynamic growth of human capital, social change and also the economy of a country (Mohammad Reza et al., 2014). Yet, what is so social about the social entrepreneurship endeavor? A few models of social entrepreneurship resulted from previous work of Mair and Noboa (2003), Gaglio (2004), Perrini and Vurro (2010), Nicholls and Cho (2008), Sommerrock (2010), El Ebrashi (2013) and Yang and Lee (2013) stated that the dimensions of social entrepreneurship influenced the achievement of individuals, organizations and communities. The early studies on social entrepreneurship have begun with the introduction of social entrepreneurship opportunities (Sommerrock 2010) based on the theory of identifying opportunities. Thus, Gaglio (2004) has come up with the Social Opportunity Identification Process Model that involves three elements, namely identification (identifying or ignoring), assessment and exploitation. This model is more focused on how individuals need to react to any social entrepreneurial opportunity.

Besides, social entrepreneurship is based on the dimensions of innovation. Social entrepreneurs are the agents of change for their communities where they will take advantage of opportunities that others do not realize such as trying to improve the system in society, creating a new approach, 
catalyzing change and creating a resilient solution to the good of the global community (Hariyaty 2014; Nicholls \& Cho 2008). Social entrepreneurs are not like profit-oriented business entrepreneurs, but they are motivated to improve society, become agents of change for society, take advantage of opportunities that others do not realize to improve the system, create new approaches and seek solutions to transform society towards more life well. The souls of social change agents owned by them will be more 'altruist' by focusing on solving community problems innovatively.

The Social Entrepreneurship Interactive Model developed by Perrini and Vurro (2010) revolves around innovation in social entrepreneurship. This model contains individual dimensions, processes dimension, environments dimension and organizations dimension as the factors that influence and directly relate to social entrepreneurship innovation. Social entrepreneurship will generate entrepreneurial activity at different scales based on innovative social attitude and based on the concept of proactive social change. In addition to innovation, entrepreneurial thinking and social change; this model also emphasizes on the reciprocal interaction between social entrepreneurs with characteristics, motivation and identification of social entrepreneurship opportunities. The study conducted by Perrini and Vurro is an exploratory study and qualitatively conducted to produce the model. The innovation that is the core of their entrepreneurial social entrepreneurship process is based on business models that focus on market orientation and stakeholders, strong network orientation, flexibility, geographical orientation and organizational structure.

\section{Methodology}

This study is a cross-sectional survey study with a population of 1531 active Enactus students from 30 participating IHEs. Sample of 500 students from 10 universities was randomly selected from the study population. Then, the 'multistage' sampling was applied to obtain 50 samples from each HEl. This sample size is more than 30 percent of the study population, and it coincides with the recommendations of Gay et al. (2009) who suggest that for a survey study, the sample should be at least 10 to 20 percent of the population. But out of the 500 samples, only 394 Enactus students managed to return the completed questionnaires (79 percent return percentage). According to Cohen et al. (2001), this amount is sufficient to enable a minimum level of field studies conducted with questionnaires percentage of return between 70 to 80 percent.

A comprehensive questionnaire using Likert scale with items designed to measure the dimensions of social entrepreneurship has been used in this study. Five-point Likert scale was used starting with 1 for "Strongly Disagree" to 5 for "Strongly Agree". This is consistent with the works of Sekaran (2003) who agree that the score of the Likert scale could be categorized as an interval scale if the total of the item scores are used to measure a construct. Based on the above recommendations, the questionnaire was drafted into 2 parts, Part A (10 items) for the purpose of obtaining the respondents' background information and followed by Part B (20 items) to measure the organization of social entrepreneurship. Items used to measure the construct of social entrepreneurship are based on the Model of Social Entrepreneurship Dimensions (Nicholls \& Cho 2008; Hariyaty et al. 2018) which encompasses of sociality, innovation and market orientation. All of the constructs and items have 
undergone content and face validation with the help of five social entrepreneurship experts from local public universities.

On top of that, a reliability scale test was carried out for all three variables of social entrepreneurship which were adapted from the early work of Nicholls and Cho (2008) and Hariyaty (2014). The internal consistency assessed for each items proven that the instrument is strongly reliable. Further, the unidimensionality of the items and sub-scales of data were evaluated by conducting a Confirmatory Factor Analysis (CFA) using Analysis of Moment Structure (AMOS). AMOS is an appropriate statistical program used to perform Structural Equation Modelling (SEM) (Hair et al. 2010). Therefore, a set of comparative index tests commonly used in most previous studies consists of Chi-square, Freedom (df), Relative Chi-square (CMIN/df), Comparative Fit Index (CFI), Tucker Lewis Index (TLI) and (Root Mean Square Error of Approximation (RMSEA) was used accordingly due to its suitability to measure the absolute fit index, incremental fit index and parsimonious fit index (Blunch 2008; Harrington 2009; Hair et al., 2010).

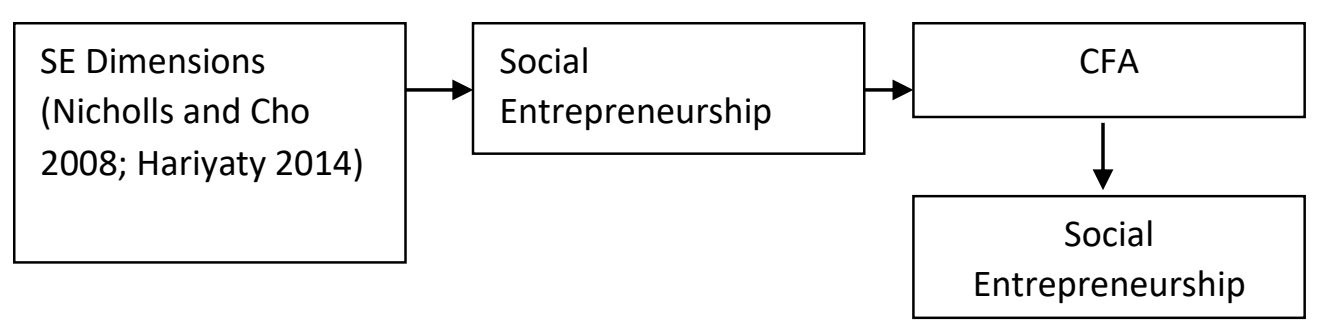

Figure 1 Conceptual Framework

\section{Research Findings}

Social entrepreneurship has been divided into three constructs namely sociality, innovation and market orientation.

\section{CFA Analysis for Sociality}

Figure 1 shows the hypothesized model of Sociality. The factor validation analysis of Maximum Likelihood Estimates show that the value of $C . R$ for regression between the latent variables of Sociality with all eight indicators (B27, B28, B29, B30, B31, B32, B33, B34) is out of the range of 1.96. Hence, the eight indicators are considered significant predictors of the Sociality latent variable at $p<.05$.

Although the initial CFA findings show that compatibility tests index such as TLI and CFI meet the criteria which is over 0.9; however, the results of the significant Relative Chi-square or CMIN/df $\left[\chi^{2}(\mathrm{n}\right.$ $=394, \mathrm{df}=20)=68.852, \mathrm{p}<0.5)]$ and the RMSEA value for the hypothesis model are greater than 0.06 and approaching 0.08 value (RMSEA $=0.079)$. Both indices depict that the hypothesized model proposed does not fit with the data as shown in Figure 2. Therefore, modification was carried out to fix the model as suggested by Hair et al. (2010). 


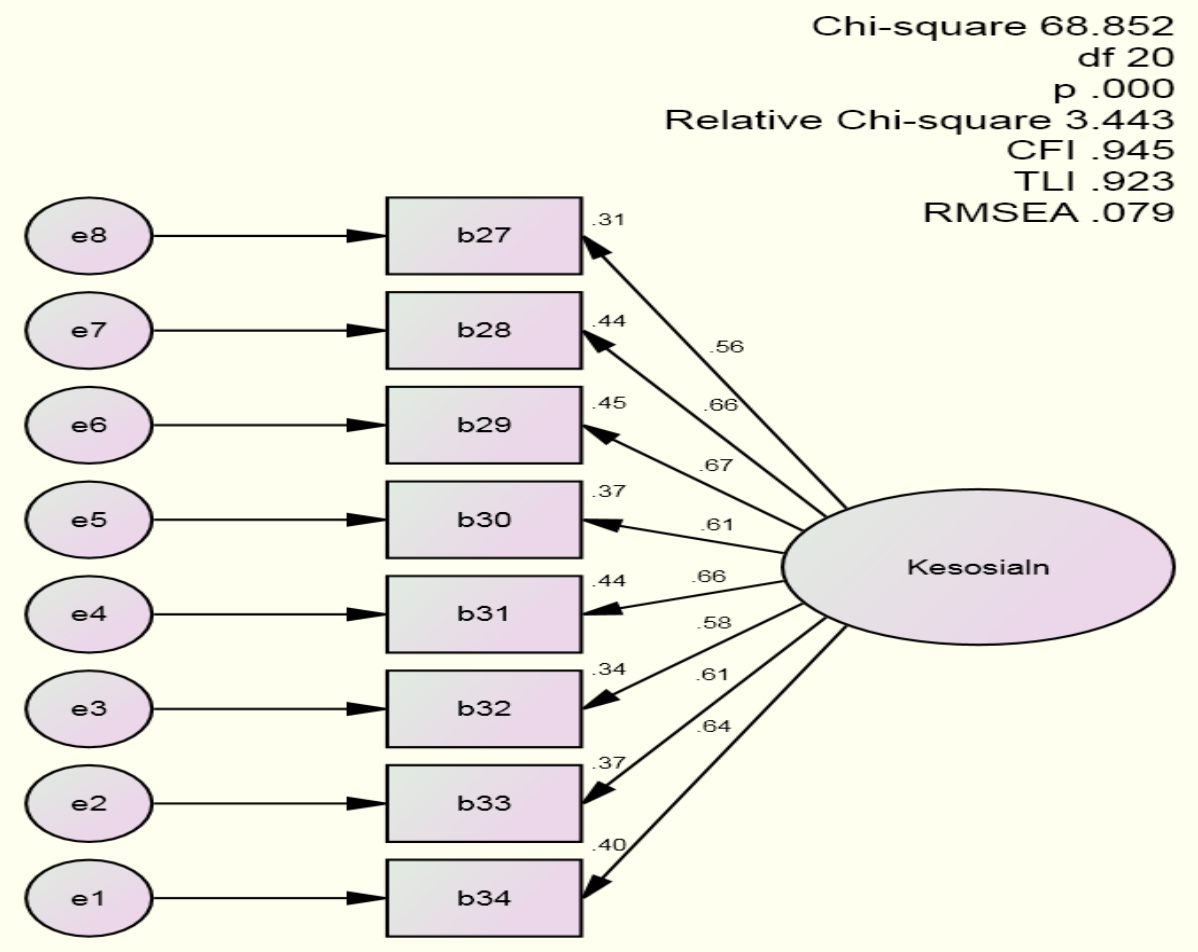

Figure 2 Hypothesized Model of Sociality

According to Tabachnich and Fidell (2007), any item measurement that has a factor impairment of less than .6 and squared multiple correlation or R2 less than 0.4 ; then the item needs to be dropped from the measurement model. By considering the above suggestion, items b27, b32 and b30 were omitted from the measurement model. After modification, the model was tested again with remaining five items as in Figure 3. The results of $\left.\mathrm{CMIN} / \mathrm{df}\left[\chi^{2}(n=394, \mathrm{df}=5)=8.787, \mathrm{p}<0.5\right)\right]$ with $\mathrm{p}$ values of .118 and RMSEA $=.044(<.08)$ indicate that the modification model for Sociality excellently fit the observed data. 

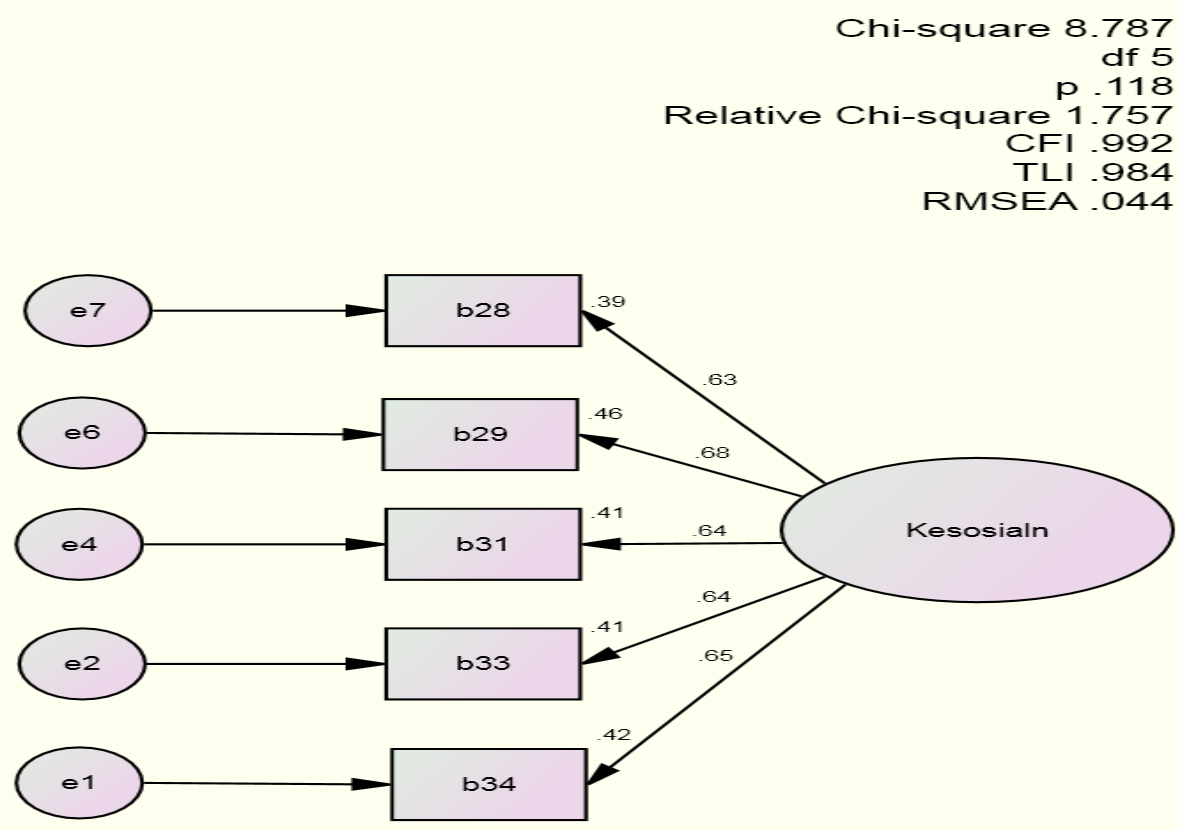

Figure 3 The Second Hypothesized Model of Sociality

The compatibility index values such as CMIN / df $=1.757$ (less than 5), $\mathrm{TLI}=.984$ and CFI $=.992$ for this modification model are higher than the first model and shows good compatibility index as are shown in Table 1.

Table 1 Confirmatory Factor Analysis for Sociality

\begin{tabular}{lllllllc}
\hline Fitness Index & $\mathrm{df}$ & $\mathrm{p}$ & $\mathrm{CMIN}$ & $\mathrm{CMIN} / \mathrm{DF}$ & $\mathrm{CFI}$ & $\mathrm{TLI}$ & $\mathrm{RMSEA}$ \\
\hline Value obtain & 5 & .118 & 8.787 & 1.757 & .992 & .984 & .044 \\
\hline
\end{tabular}

Table 2 Regression Weight for Sociality Measurement Model

\begin{tabular}{|c|c|c|c|c|}
\hline Item & Estimated Loading & S.E. & C.R. & $P$ \\
\hline B34 & .646 & * & $*$ & $*$ \\
\hline B33 & .640 & .104 & 9.751 & 0.001 \\
\hline B31 & .638 & .102 & 9.735 & 0.001 \\
\hline B29 & .678 & .111 & 10.128 & 0.001 \\
\hline B28 & .627 & .109 & 9.608 & 0.001 \\
\hline
\end{tabular}

Table 2 as above describes the estimated loading, standard error (S.E), Critical Ratio (C.R) and the $p$ value for each item. The value of C.R which is outside the range of \pm 1.96 is significant $(p<.05)$. Each 
INTERNATIONAL JOURNAL OF ACADEMIC RESEARCH IN BUSINESS AND SOCIAL SCIENCES

Vol. 8, No. 11, Nov, 2018, E-ISSN: 2222-6990 @ 2018 HRMARS

items is considered significantly correlated with Sociality when the estimated loading value is greater than 0.6 . The symbol * indicates that the regression coefficient of the item is set to 1 to minimize the number of parameters to be estimated (Hair et al., 2010).

\section{CFA Analysis for Innovation}

Figure 4 shows the hypothesized model for Innovation constructs. The results of the factor validation analysis with Maximum Likelihood Estimates show that $C$. $R$ value between the latent variable and the indicators (B35, B36, B37, B38, B39, B40) is beyond \pm 1.96 . Therefore, the six item indicators are significant predictors of Innovation $(p<.05)$. Preliminary findings of the CFA show that CFI is over 0.9; but not the TLI compatibility index. The significant results of the CMIN $\left[\left(\chi^{2}(n=394, d f=9)=66.640\right.\right.$, $\mathrm{p}<0.5)$ ] and RMSEA $=0.128$ indicates that the hypothesized model does not fit the observed data as shown in Figure 4.

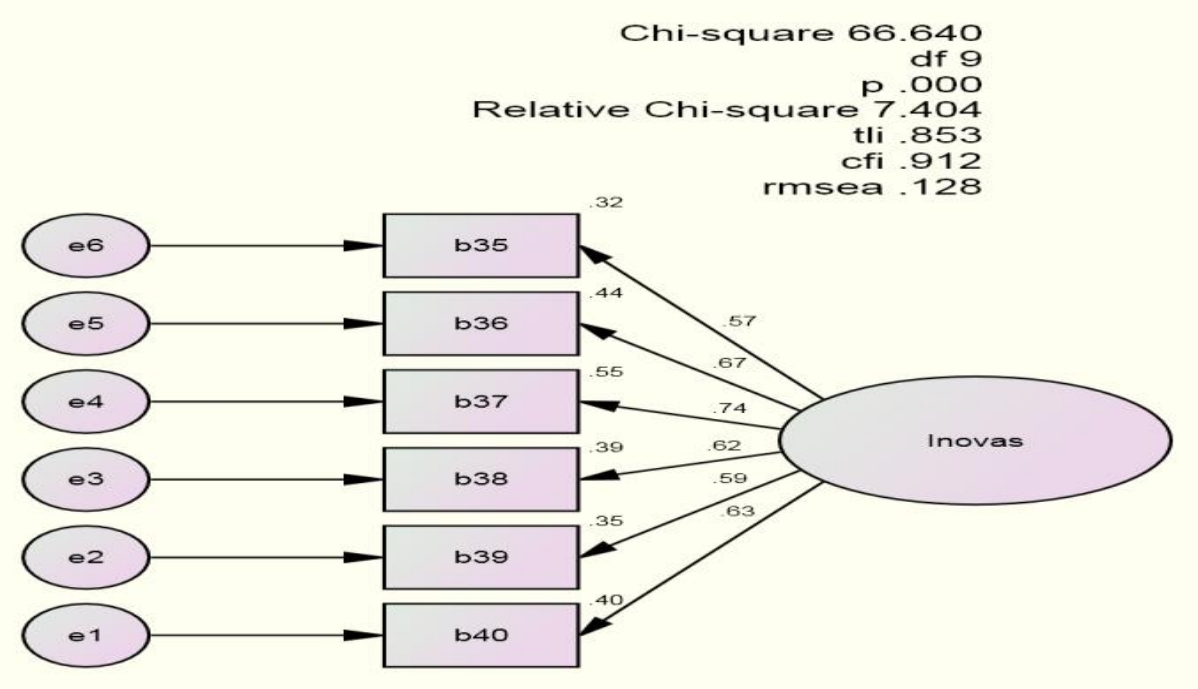

Figure 4 Hypothesized Model for Innovation

Based on CMIN/df and RMSEA results, the hypothesized model misfits the observed data and thusly requires modification. Therefore, items b35 and b36 were dropped from the measurement model (Figure 5). 

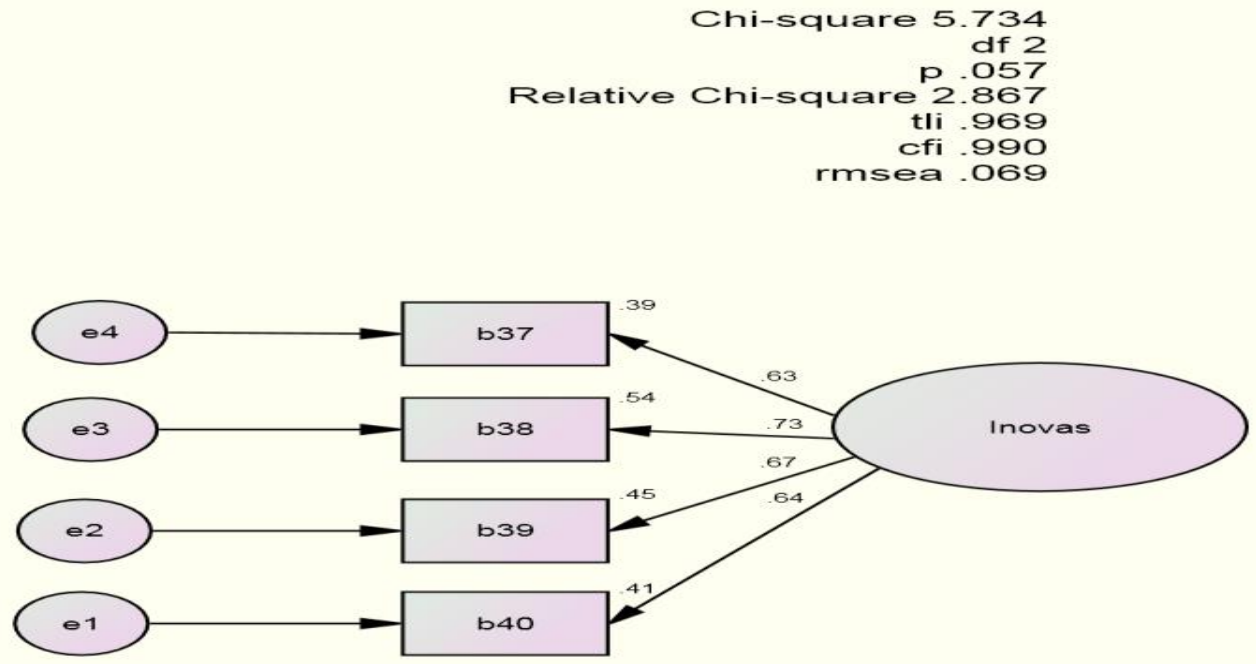

Figure 5 The Second Hypothesized Model of Innovation

The above model shows that CMIN $\left.\left[\chi^{2}(n=394, d f=2)=5.734, p<0.5\right)\right]$ with $p$ values of .057 and RMSEA $=.069(<.08)$ indicates that the modification model for Innovation does fit the observed data. Compatibility index values such as CMIN / df is 2.867 (less than 5), TLI = .969 and CFI = .990 as shown in Table 3 are higher than the original hypothesized model of Innovation thus depicts good compatibility index.

Table 3 Confirmatory Factor Analysis for Innovation

\begin{tabular}{lllllllc}
\hline Fitness Index & $\mathrm{df}$ & $\mathrm{p}$ & $\mathrm{CMIN}$ & $\mathrm{CMIN} / \mathrm{DF}$ & $\mathrm{CFI}$ & $\mathrm{TLI}$ & RMSEA \\
\hline $\begin{array}{l}\text { Value } \\
\text { obtained }\end{array}$ & 2 & .057 & 5.734 & 2.867 & .990 & .969 & .069 \\
\hline
\end{tabular}

Table 4 Regression Weight for Innovation Measurement Model in Organizing Social Entrepreneurship

\begin{tabular}{|c|c|c|c|c|}
\hline Item & Estimated Loading & S.E. & C.R. & $P$ \\
\hline B40 & .640 & $*$ & $*$ & $*$ \\
\hline B39 & .671 & .107 & 9.756 & 0.001 \\
\hline B38 & .734 & .113 & 10.125 & 0.001 \\
\hline B37 & .626 & .106 & 9.349 & 0.001 \\
\hline
\end{tabular}


INTERNATIONAL JOURNAL OF ACADEMIC RESEARCH IN BUSINESS AND SOCIAL SCIENCES

Vol. 8, No. 11, Nov, 2018, E-ISSN: 2222-6990 @ 2018 HRMARS

Next, Table 4 shows the estimated loading, standard error (S.E), Critical Ratio (C.R) and the $p$ value for each item. The value of C.R which is outside the range of \pm 1.96 and considered as significant at the level of $p<.05$. Each item is correlated significantly with innovation with estimated loading value greater than 0.6 .

\section{CFA Analysis for Market Orientation}

Figure 6 shows the hypothesized model for Market Orientation construct. The result of the validation factor analysis with Maximum Likelihood Estimates shows that the value of Critical Ratio (C.R) for regressions between Innovative latent variables with the six indicators (B41, B43, B44, B45, B46, B48) is beyond \pm 1.96 . Therefore, these six indicators are considered significant predictors of the latent variables namely Market Orientation ( $p<.05)$.

Preliminary findings of the CFA show a significant result of CMIN $\left[\chi^{2} \quad(n=394, d f=9)=21.223, p\right.$ $<0.5$ ]. However, the RMSEA value which is smaller than 0.08 (RMSEA $=0.059$ ) and CMIN/df value smaller than 5 indicated that the hypothesized model of Market Orientation fits the observed data. Compatibility index tests such as CFI and TLI also meet the compatibility index criteria which is above 0.9. The indices are shown in Figure 6 and Table 5.

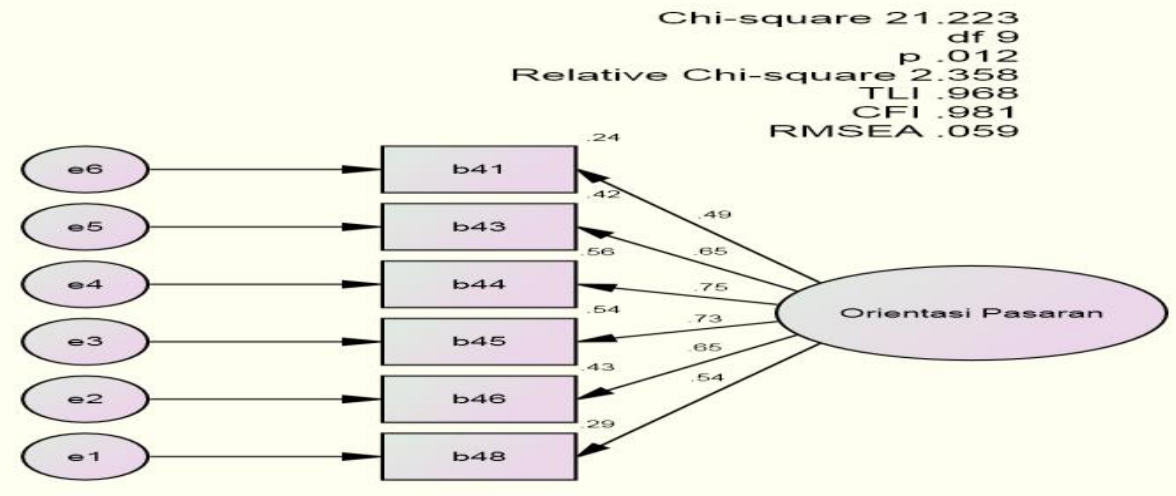

Figure 6 Hypothesized Model for Market Orientation Table 5 Confirmatory Factor Analysis for Market Orientation

\begin{tabular}{lllllllc}
\hline Fitness index & $\mathrm{df}$ & $\mathrm{p}$ & $\mathrm{CMIN}$ & $\mathrm{CMIN} / \mathrm{DF}$ & $\mathrm{CFI}$ & $\mathrm{TLI}$ & RMSEA \\
\hline $\begin{array}{l}\text { Value } \\
\text { obtained }\end{array}$ & 9 & .012 & 21.223 & 2.358 & .981 & .968 & .059 \\
\hline
\end{tabular}

Next, Table 6 shows the estimated loading, standard error (S.E), Critical Ratio (C.R) and p value for each item. The value of $C . R$ which is outside the range of \pm 1.96 is considered as significant at the level of $p<.05$. Each item is significantly correlated with Market Orientation where each factor is found greater than 0.4 .

Table 6 Regression Weight for Market Orientation Measurement Model in Organizing Social Entrepreneurship 
INTERNATIONAL JOURNAL OF ACADEMIC RESEARCH IN BUSINESS AND SOCIAL SCIENCES

Vol. 8, No. 11, Nov, 2018, E-ISSN: 2222-6990 @ 2018 HRMARS

\begin{tabular}{|c|c|c|c|c|}
\hline Item & Estimated Loading & S.E. & C.R. & $\mathrm{P}$ \\
\hline B48 & .537 & $*$ & $*$ & $*$ \\
\hline B46 & .653 & .107 & 8.977 & 0.001 \\
\hline B45 & .734 & .113 & 9.537 & 0.001 \\
\hline B44 & .749 & .106 & 9.620 & 0.001 \\
\hline B43 & .652 & .145 & 8.964 & 0.001 \\
\hline B41 & .487 & .119 & 7.424 & 0.001 \\
\hline
\end{tabular}

Since the first order CFA for each social entrepreneurship dimensions have achieved the desired requirements, the second order CFA testing should takes place. The CFA analysis of the second order measurement model is made only once as the regression coefficient value is found to be greater than .4. Compatibility index values such as CFI, TLI, CMINDF and RMSEA are shown in Table 7. Items of Social Entrepreneurship are significant at 0.001 (Refer to Table 8).

Table 7 Analysis of Confirmative Factor Analysis for Social Entrepreneurship Hypothesized Model

\begin{tabular}{llllllll}
\hline Fitness Index & df & $p$ & CMIN & CMIN/DF & CFI & TLI & RMSEA \\
\hline $\begin{array}{l}\text { Value } \\
\text { obtained }\end{array}$ & 87 & 0.000 & 164.359 & 1.889 & .957 & .948 & .048 \\
\hline
\end{tabular}

Table 8 Regression Weight for Social Entrepreneurship Dimensions

\begin{tabular}{lcccc}
\hline \multicolumn{1}{c}{ Correlation } & Correlation Coefficient & S.E. & C.R. & $P$ \\
\hline Market Orientation and Innovation & .702 & .016 & 7.055 & 0.001 \\
Sociality and Innovation & .635 & .015 & 7.062 & 0.001 \\
Market Orientation and Sociality & .613 & .014 & 6.635 & 0.001 \\
\hline
\end{tabular}

Convergence validity is obtained by examining the correlation between the items with the number of sub-scales scores measured. Items have a high convergence validity if the correlation between items with the sub-structured scores measured by them is high and this indicates that the item really measures what should be measured. The convergent validity of the CFA Measurement Model can be referred to in Table 9. The discrimination validity is shown in Table 8 and shows that the value of the Average Variance Extracted (AVE) obtained is greater than .40 and considered acceptable (Hair et al., 2010). The information pertaining to this study's compatibility index and its references can be referred to Table 9. 
INTERNATIONAL JOURNAL OF ACADEMIC RESEARCH IN BUSINESS AND SOCIAL SCIENCES Vol. 8, No. 11, Nov, 2018, E-ISSN: 2222-6990 @ 2018 HRMARS

Table 9 Measurement Model based on Confirmatory Factor Analysis (CFA)

\begin{tabular}{|c|c|c|c|c|c|}
\hline \multicolumn{6}{|c|}{ Convergent Validity } \\
\hline Construct & Item & $\begin{array}{l}\text { Internal consistency } \\
\text { Cronbach's Alpha }\end{array}$ & $\begin{array}{l}\text { Factor } \\
\text { Loadings }\end{array}$ & $\begin{array}{l}\text { Composite } \\
\text { reliability }^{a}\end{array}$ & $\begin{array}{l}\text { Average } \\
\text { variance } \\
\text { extracted }^{b}\end{array}$ \\
\hline \multirow[t]{5}{*}{ Sociality } & B28 & 0.78 & .63 & 0.96 & 0.42 \\
\hline & B29 & & .68 & & \\
\hline & B31 & & .64 & & \\
\hline & B33 & & .64 & & \\
\hline & B34 & & .65 & & \\
\hline \multirow[t]{4}{*}{ Innovation } & B37 & 0.76 & .63 & 0.76 & 0.45 \\
\hline & B38 & & .73 & & \\
\hline & B39 & & .67 & & \\
\hline & $\mathrm{B} 40$ & & .64 & & \\
\hline \multirow{7}{*}{$\begin{array}{l}\text { Market } \\
\text { Orientation }\end{array}$} & B41 & 0.80 & .49 & & \\
\hline & & & & 0.80 & 0.41 \\
\hline & B43 & & .65 & & \\
\hline & B44 & & .75 & & \\
\hline & B45 & & .73 & & \\
\hline & B46 & & .65 & & \\
\hline & B48 & & .65 & & \\
\hline
\end{tabular}

Notes:

a Composite reliability

${ }^{b}$ Composite reliability

Table 10 The Discrimination Validity of Constructs

\begin{tabular}{lccc}
\hline \multicolumn{1}{c}{ Constructs } & $(1)$ & $(2)$ & $(3)$ \\
\hline (1) Sociality & $\mathbf{0 . 6 5}$ & 0.40 & 0.38 \\
(2) Innovation & 0.64 & $\mathbf{0 . 6 7}$ & 0.49 \\
(3) Market Orientation & 0.61 & 0.70 & $\mathbf{0 . 6 4}$ \\
\hline
\end{tabular}

Notes: The value on the diagonal diagonal represents the AVE square root while the other value represents the dual-power correlation. 
INTERNATIONAL JOURNAL OF ACADEMIC RESEARCH IN BUSINESS AND SOCIAL SCIENCES Vol. 8, No. 11, Nov, 2018, E-ISSN: 2222-6990 @ 2018 HRMARS

Table 11 Compatibility Index for Social Entrepreneurship Measurement Model

\begin{tabular}{lccl}
\hline Fitness Index & Study Results & Proposed Value & \multicolumn{1}{c}{ Reference } \\
\hline $\mathrm{df}$ & 87 & & \\
$\chi^{2}$ & 164.359 & $\leq 3.00$ & $\begin{array}{l}\text { Gefen et al. (2000), Zainuddin } \\
(2013)\end{array}$ \\
$\chi^{2} / \mathrm{df}$ & 1.889 & $\geq 0.90$ & $\begin{array}{l}\text { Bagozzi dan Yi (1988), } \\
\text { Zainuddin (2013) }\end{array}$ \\
$\mathrm{CFI}$ & 0.957 & & $\begin{array}{l}\text { Zainuddin (2013) } \\
\text { RMSEA }\end{array}$ \\
TLI & 0.048 & $\leq 0.08$ & Bagozzi dan Yi (1988), \\
& 0.948 & $\geq 0.90$ & Zainuddin (2013) \\
\hline
\end{tabular}

Chi-square 164.359

df 87

p. 000

Relative Chi-square 1.889

CFI .957

TLI .948

RMSEA .048

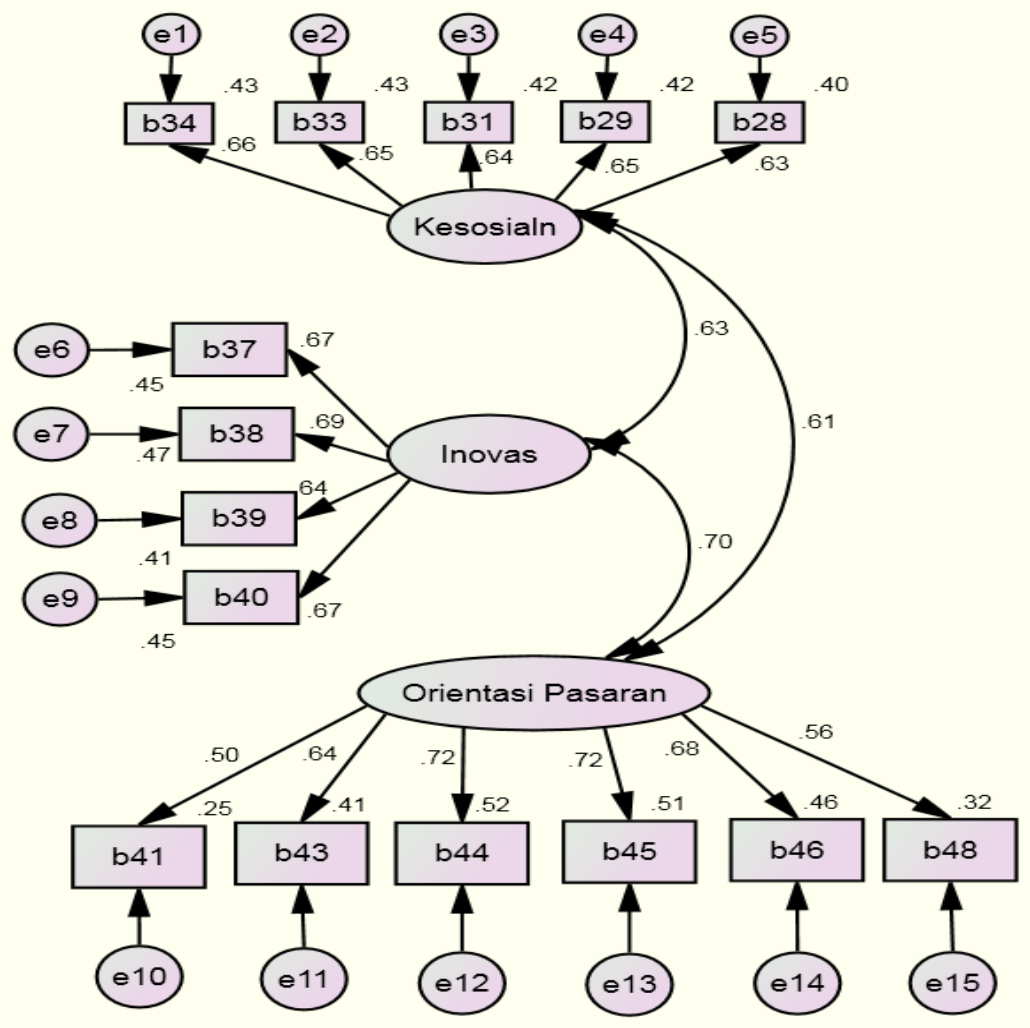

Figure 7 Measurement Model for Social Entrepreneurship Dimension 
INTERNATIONAL JOURNAL OF ACADEMIC RESEARCH IN BUSINESS AND SOCIAL SCIENCES

Vol. 8, No. 11, Nov, 2018, E-ISSN: 2222-6990 C 2018 HRMARS

Based on the CFA analysis made for social entrepreneurial organizational measurement model consisting of three constructs, namely sociality, innovation and market orientation as shown in Figure 7; it is found that the model fits the observed data.

\section{Conclusion}

This study highlights the needs to inculcate social entrepreneurship among the public university students. In line with that, an establish measurement model which is still at scant needs to be constructed and validated to gauge the outcomes of any social entrepreneurship activities. The findings of this study reveal that the measurement model constructed for social entrepreneurship dimensions namely sociality, innovation and market orientation fits the study data. Theoretically, the findings of this study empirically prove that Social Entrepreneurship dimension constitutes of sociality, innovation and market orientation. This finding also confirms that the entrepreneurial dimension can be referred to in the context of Malaysian public university students who participate in social entrepreneurship programs at universities. This also helps to expend the social entrepreneurship theory which is insufficient as well. Practically, this study has succeeded in producing a social entrepreneurial measurement model that can be used by management at public universities to measure the dimensions of social entrepreneurship of students participating in social entrepreneurship programs. Besides, the study provides a Social Entrepreneurship Measurement Model that can be used by educators and practitioners of any social entrepreneurship endeavor to develop the capacity of social entrepreneurs at the tertiary level especially among the public universities' students. Social entrepreneurship indicators and models proposed by this study can be used as sources of reference to develop more social entrepreneurship instruments in future.

\section{References}

Blunch, N. (2008). Introduction to Structural Equation Modelling Using SPSS and AMOS. Los Angeles: Sage Publication.

Bornstein, D. (2007). How to Change the World: Social Entrepreneurs and The Power of New Ideas. USA: Oxford University Press.

Bornstein, D. \& Davis, S. (2010). Social Entrepreneurship: What Everyone Needs to Know. USA: Oxford University Press.

Brooks, A. C. (2009). Social Entrepreneurship: A Modern Approach to Social Value Creation. New Jersey: Prentice Hall.

Cohen, L., Manion, L. \& Morisson, K. (2001). Research Methods in Education. 5th Edition. London: Routledge Falmer.

El Ebrashi, R. 2013. Social Entrepreneurship Theory and Sustainable Social Impact. Social Responsibility Journal 9(2): 65-74. 
INTERNATIONAL JOURNAL OF ACADEMIC RESEARCH IN BUSINESS AND SOCIAL SCIENCES

Vol. 8, No. 11, Nov, 2018, E-ISSN: 2222-6990 C 2018 HRMARS

Emerson, J. (2003). The blended value proposition: integrating social and financial returns. California Management Review 45(4):35-51.

Farhana, R. (2013). Pembudayaan Keusahawanan Ke Arah Mempengaruhi Kecenderungan Menceburi Bidang Keusahawanan Dalam Kalangan Bakal Graduan Di UTHM. Laporan Projek Sarjana. Fakulti Pendidikan Teknikal dan Vokasional. Universiti Tun Hussein Onn Malaysia.

Gaglio, C.M. (2004). The role of mental simulations and counterfactual thinking in the opportunity identification process. Entrepreneurship: Theory and Practice 28(6): 533-552

Gatchalian, M.L. (2010). An in-depth analysis of the entrepreneurship education in the Phillippines: an initiative towards the development of a framework for a professional teaching competency program for entrepreneurship educators. The International Journal of Research and Review 5: 51-73.

Gay, L.R., Mills, G. E. \& Airasian, P. (2009). Educational Research-Competencies for Analysis and Applications. Edisi ke-9. New Jersey: Pearson Education Ltd.

Hair, J.F, Black, W., Babin, B.J, \& Anderson, R.E. (2010). Multivariate Data Analysis. 7th Edition. USA: Prentice-Hall, Inc.

Hariyaty Ab Wahid, Norasmah Othman \& Suria Mohd Salleh. (2013). Social entrepreneurship contributions on the competitiveness of active students in the Students in Free Enterprise Program (SIFE) Malaysia. Proceedings of 6th International Seminar on Regional Education UKM-UNRI2013, 1919-1929.

Hariyaty Ab Wahid, Noor Lela Ahmad, Norasmah Othman \& Wan Salmuni Wan Mustaffa. (2016). Kesosialan, Inovasi dan Orientasi Pasaran dalam Kalangan Pelajar Aktif Keusahawanan Sosial di Universiti Awam Malaysia, Journal of Global Business and Social Entrepreneurship (GBSE) 1(2): 1-9.

Hariyaty Ab Wahid, Wan Salmuni Wan Mustaffa, Rafiduraida Abdul Rahman, Noor Lela Ahmad, Muhd Khairuddin Lim Abdullah. (2018). Inculcating the trait of altruism through social entrepreneurship program among university students of Malaysia, Journal of Global Business and Social Entrepreneurship (GBSE) 4(11): 104-112.

Hashim S., \& Radio N. (2011). Ciri Personaliti Keusahawanan Pelajar Tahun 2 SPH. Fakulti Pendidikan Universiti Teknologi Malaysia Skudai, Johor.

HEls Entrepreneurship Development Policy. (2010). Kementerian Pengajian Tinggi Malaysia. http://www.portal.mohe.gov.my/portal/page/portal/ExtPortal/MOHE MAIN PAGE/NEWSEVENTS/p ublication/dasar pbgn keusahawanan ipt.pdf. [21 September 2018]. 
INTERNATIONAL JOURNAL OF ACADEMIC RESEARCH IN BUSINESS AND SOCIAL SCIENCES

Vol. 8, No. 11, Nov, 2018, E-ISSN: 2222-6990 @ 2018 HRMARS

Ministry of Higher Education. (2016). Pelan Tindakan Keusahawanan IPT 2016-2020. http://www.mohe.gov.my/index.php/fokus/231-pelan-tindakan-keusahawanan-ipt-2016-2020. [21 September 2018].

Katono, I.W. (2011). Construction of an instrument to measure social valuation in an emerging market context. Education + Training 53(5): 371-386.

Litzky, B.E., Godshalk, V.M. \& Walton-Bongers, C. (2010). Social entrepreneurship and community leadership: a service-learning model for management education. Journal of Management Education 34(1): 142-162.

Mair, J. \& Marti, I. (2005). Social entrepreneurship research: a source of explanation, prediction and delight. Working Paper. IISE Business School-University of Navarra, Spain. Mac 2004.

Mair. J. \& Noboa, E. (2003). Social entrepreneurship: How intentions to create a social enterprise get formed. Working Paper. IESE Business School- Universidad of Navarra,1-20.

Mazura Mansor. (2015). Keberkesanan Pembelajaran Berasaskan Konsultasi Terhadap Tekad Keusahawanan Pelajar Politeknik. Unpublished Doctoral Thesis. Fakulti Pendidikan, UKM Bangi, Malaysia.

Ministry of Higher Education. (2007). Asas Pembudayaan Keusahawanan. Kedah: Penerbit Universiti Utara Malaysia.

Marshall, R.S. (2010). Conceptualizing the international for-profit social entrepreneur. Journal of Business Ethic. Springer Published Online.

Megre, R., Martins, M.A. \& Salvado, J.C. (2012). ES+ Methodology: mapping social entrepreneurship. ACRN Journal of Entrepreneurship Perspectives 1(1): 97-110.

Mohammad Reza Noruzi, Westover, J.H., \& Gholam Reza Rahimi. (2010). An exploration of social entrepreneurship in the entrepreneurship era. Asian Social Science 6(6): 3-10.

Norasmah Othman \& Hariyaty Ab Wahid. (2014). Social Entrepreneurship among participants in the students in free enterprise program. Education + Training 56(8/9): 852-869.

Norhamizah Jalaluddin. (2017). Faktor Keengganan Terhadap Kerjaya Keusahawanan Dalam Kalangan Pelajar Bumiputera Tahun Akhir Di Universiti Berfokus Wilayah Utara. Unpublished Master Thesis. Universiti Pendidikan Sultan Idris. 
INTERNATIONAL JOURNAL OF ACADEMIC RESEARCH IN BUSINESS AND SOCIAL SCIENCES Vol. 8, No. 11, Nov, 2018, E-ISSN: 2222-6990 (C) 2018 HRMARS

Nga, J.K.H. \& Shamuganathan, G. (2010). The influence of personality traits and demographic factors on social entrepreneurship start up intentions. Journal of Business Ethics, 95:259-282.

Nicholls, A. \& Cho, A.H. (2008). Social entrepreneurship: the structuration of a field. In. Nicholls, A (Ed). 2008. Social Entrepreneurship: New Models of Sustainable Social Change. New York: Oxford University Press.

Prahalad, C.K. (2005). The Fortune at The Bottom of The Pyramid: Eradicating Poverty Through Profit. London: Wharton School Publishing.

Perrini, F. \& Vurro, C. (2010). Developing an Interactive Model of Social Entrepreneurship. In. Hockerts, K., Mair, J. \& Jeffrey Robinson (Ed). Values and Opportunities in Social Entrepreneurship, 165-180. New York: Palgrave MacMillan.

Radin Siti Aishah Radin A Rahman, Norasmah Othman, Zaidatol Akmaliah Lope Pihie, Hariyaty Ab. Wahid. (2016). Entrepreneurial Intention and Social Entrepreneurship among Students in Malaysian Higher Education. World Academy of Science, Engineering and Technology International Journal of Social, Behavioral, Educational, Economic, Business and Industrial Engineering 10(1): 175-181.

Sekaran, U. (2003). Research Methods for Business: A Skill Building Approach. Edisi ke-4. Singapore: John Wiley \& Sons (Asia) Pte. Ltd.

Sommerrock, K. (2010). Social Entrepreneurship Business Models: Incentive Strategies to Catalyze Public Goods Provision. UK: Palgrave Macmillan.

Suraini Mohd Rhouse, Noor Lela Ahmad, Hariyaty Ab Wahid \& Nek Kamal Yeop Yunus. (2016). Social enterprising values among women entrepreneurs. In. Social Entrepreneurship and Community Engagement: Transforming Societies. Institut Sosial Malaysia: Kuala Lumpur.

Suraiya Ishak \& Ahmad Rafflis Che Omar. (2015). Keusahawanan sosial sebagai satu pendekatan inovatif ke arah transformasi sosial masyarakat: Kajian kes di Malaysia. GEOGRAFIA OnlineTM Malaysian Journal of Society and Space 11 (8): 38 - 51.

Syed Zamberi Ahmad. (2013). The need for inclusion of entrepreneurship education in Malaysia lower and higher learning institutions. Education + Training 55(2): 191-203.

Tan, W- L., William, J. \& Tan, T-M. (2005). Defining the 'social' in 'social entrepreneurship': altruism and entrepreneurship. International Entrepreneurship and Management Journal (1): 353-365.

Verma, A. (2009). Social Entrepreneurship Management- A New Look at the People and the Potential. New Delhi: Global India Publications Pte. Ltd. 
INTERNATIONAL JOURNAL OF ACADEMIC RESEARCH IN BUSINESS AND SOCIAL SCIENCES Vol. 8, No. 11, Nov, 2018, E-ISSN: 2222-6990 (C) 2018 HRMARS

Yang, C-L. \& Lee,Y-C. (2013). Building performance assessment model for social enterprise - view of creating social values. Business and Information (Bali, July 7-9): 206-218.

\section{Acknowledgements}

This research is funded by Universiti Pendidikan Sultan Idris Research Grant (2017-0158-106-01).

\section{Corresponding Author}

Dr. Hariyaty Ab Wahid

Department of Business Management and Economics, Faculty of Business and Management

Universiti Pendidikan Sultan Idris, 35900 Tanjong Malim,

Malaysia.

Email: hariyaty@fpe.upsi.edu.my 